Pre-print chapter of Handbook of Human Symbolic Evolution (edited by Nathalie Gontier, Oxford University Press)

\title{
Symbolism and Archaeoastronomy in Prehistory
}

\author{
Fernando Pimenta, Fabio Silva and Luís Tirapicos
}

\begin{abstract}
The study of how people engage with the sky is known as cultural astronomy, a term that comprises any field concerned with sky and culture, including the history of astrology, the history of astronomy, ethnoastronomy and archaeoastronomy. The latter focuses on analysing the archaeological record for evidence of past skyscapes, i.e. past forms of engagement with the sky and the celestial objects, and how they would feature in the cosmologies of the societies under study. In this chapter we explore the relations of prehistoric groups with the sky in their symbolic and conceptual implications. This is followed by six case studies from the western part of the Iberian Peninsula, representative of prehistoric contexts found in other parts of the world, that range from megalithic structures to rock art and caves. These case studies illustrate how prehistoric skyscapes provided not only spatial axes for the construction of structures that align with celestial objects and events but, perhaps more importantly, how they also served as temporal anchors moored to important environmental and social moments of transition.
\end{abstract}

Keywords: cultural astronomy, skyscape, structural orientation, cosmology, prehistory, rock art, megalithism

The sky is filled with entities - the sun, the moon, the planets, individual stars, asterisms and constellations, the milky way - that are as much a part of the environment of a given society as the land, trees, animals, birds, mountains, rivers, lakes and the sea that surrounds them. As such, they are prone to feature in the world(s) conceived by such societies. The celestial objects can be conceived of as animate beings, with agency and social relations between themselves and the wider environment: 'Human societies often people their skies with supernaturals, ancestors or mythological heroes to whom they become related through family ties, mythological narratives, political alliances or power relationships.' (Iwaniszewski 2011: 31).

The daily and seasonal disappearances and reappearances of celestial bodies might be linked, symbolically or functionally, with other cycles of the environment and thereby form symbolic templates for processes of individual and social renewal and transformation, such as those played out in rites of passage (e.g. Hayden and Villeneuve 2011) and funerary rites (e.g. Brady 2012); or provide the timing for religious and magical practices (e.g. Boutsikas and Ruggles 2011), feasts and massive gatherings (e.g. Hayden and Villeneuve 2011), seasonal migratory activities (e.g. Silva 2015b) and key moments in the hunting, gathering and agricultural yearly cycles (e.g. Ruggles 2015b). It therefore should not come as a surprise to find the celestial bodies intricately tied to the notions of time and even to the calendars of so many societies worldwide (e.g. Aveni 2000; Campion 2012). Such skyscapes act not only as temporal anchors for society but can also provide spatial axes: key moments in the transits of the celestial bodies through the skies can be seen to highlight cosmological directions that can act as navigational guides (e.g. 
Pre-print chapter of Handbook of Human Symbolic Evolution (edited by Nathalie Gontier, Oxford University Press)

Brady 2015b; Pimenta 2015) or become spatial templates to be replicated, or targeted, by the built environment.

\section{The Study of Cultural Astronomy}

The study of how people engage with the sky is known as cultural astronomy (Ruggles and Saunders 1993). It is perhaps more appropriately conceived of as an umbrella term that encapsulates any field concerned with sky and culture. It therefore subsumes under its span such fields as the history of astronomy, the history of astrology, ethnoastronomy - which focuses on the ethnographic record - and archaeoastronomy - which focuses on the archaeological record. As a field of academic inquiry, archaeoastronomy predates its younger siblings, its origins being lost in $19^{\text {th }}$-century antiquarianism (Ruggles 1999; Hutton 2013). However, it has traditionally had a specific focus on the orientations of monumental structures, in particular trying to identify intentional alignments to celestial objects. It reached popular status in the 1960s when claims that a vast number of solar and lunar alignments were intentionally built into the architecture of the prehistoric stone circle of Stonehenge (England) generated a heated debate between archaeologists and archaeoastronomers (Hawkins 1963, Atkinson 1966). Ever since, and despite ebbs and flows, the field turned back on itself, rarely engaging with archaeologists and preferring to present and publish findings in their own conferences and proceedings volumes.

As a reaction to this lack of cooperation and cross-field engagement between archaeologists and archaeoastronomers, the notion of a skyscape archaeology has been recently introduced (Henty 2014; Silva 2014). This relocates the debate firmly within the wider discipline of archaeology by engaging with the wider archaeological record (both material and environmental) while embracing the anthropological concept of reflexivity as a methodological necessity to overcome modern assumptions and Eurocentric biases, and taking a less monolithic stance with regards to the theoretical frameworks that underpin research questions, data analyses and subsequent interpretations (Silva 2017, Silva and Henty 2018). The concept of skyscape, therefore, emerged as an unbiased term to refer to a society's relationship to what we call the sky and the celestial bodies (Silva 2015a; 2017).

\section{Celestial Symbolism in the Material Record}

The three dimensions of a skyscape mentioned in the beginning of this article (animism, timing and direction) find materiality - and hence find themselves encoded in the material record - in a number of ways. One such way, and the way that has been more popularized within archaeoastronomy, is that of structural orientations. The very word orientation betrays an emphasis on the East, which might relate to the medieval prescription to build churches so that the audience is facing East, i.e. the rising sun, and hence symbolically facing the risen Christ. These, however, seem to be more symbolic prescriptions that functional instructions as most churches' orientation deviate from east in yet to be fully understood ways (McCluskey 2015). Nevertheless, some structures, in either their symmetry or in the placement of unique architectural features, do encode functional alignments to celestial objects at key moments in time. Famous prehistoric examples include the already mentioned stone circle of Stonehenge (England), with its axis aligning precisely with sunset on December solstice (Ruggles 1999), and Newgrange (Ireland), a passage grave that features a roof-box above its entrance that permits 
Pre-print chapter of Handbook of Human Symbolic Evolution (edited by Nathalie Gontier, Oxford University Press)

the light of the rising sun to penetrate its otherwise dark chambers on December solstice (Prendergast 2011). Many other examples of complex structures that encode celestial alignments can be found for a variety of cultures worldwide and across different time periods (for many examples see Aveni 2008; Ruggles 2015a). Depending on the socio-cultural context, such structural alignments might have been built to produce unique experiences when observing celestial objects (e.g. Harding et al 2009), to establish light/shadow interactions with the built and natural environments that might be conceived of as hierophanies (e.g. Rivard 1970), or to animate what we would otherwise consider inert matter (e.g. Malville 2015a).

The temporal anchoring that the celestial bodies provide can find its way into the material record also via structural orientations: as celestial bodies are often visible only periodically, they match the directions of buildings only at key moments in time when heaven and earth might be conceived as being in alignment. Examples include the already mentioned solstice alignments, but also those moments when the sun is vertically above, at the zenith, and therefore no shadows are cast - a phenomena that can only happen for locations in-between the Tropics of Cancer and Capricorn around noon on very specific days of the year (e.g. Sprajc 2018); when the moon rises and sets at an extreme position where the sun never rises nor sets throughout the entire year - a phenomena that only occur every 18.6 years (e.g. Malville 2015b); or when a star is seen to rise in the dawn's twilight, prior to the sun, for the first time after a period when it was absent from the night sky (e.g. Brady 2015a).

Another way in which the temporal dimensions of skyscapes can be materialized is through tallies. It has been suggested that marks in incised bone and ivory implements from the European Upper Palaeolithic could record lunar and solar observations in some form of calendrical notation (Marshack 1991). Their shapes, positions on the bone plaquettes and numbers were suggestive of the recording lunar phases and using them to count days between lunations, as well as between solstices. These interpretations, or at least their widespread generality, have been more recently critiqued (e.g. D'Errico 1989, Hayden and Villeneuve 2011). Yet, another case comes from one of the Neolithic temples of Mnajdra (Malta) which features two limestone slabs with series of dots forming differently sized lines. The number of dots on each line, as well as the number of lines, have been observed to match the number of days separating the first morning rising of particularly bright stars (Ventura et al 1993).

But skyscapes are not just 'good to think' about temporal and spatial dimensions, they also offer a rich visual canvas which often finds its way into iconography and art. Examples abound of prehistoric rock art with motifs that have been interpreted as representations of celestial objects, including constellations (e.g. Rappenglück 2015) and even supernovas (e.g. Aveni 1993), or with motifs that are activated, or perhaps animated, through their interaction with sunlight (e.g. Sofaer et al 1979). Many such cases have been the object of critique mostly because of the projection of ethnocentric and anachronistic modern skyscapes unto non-modern peoples (e.g. Carlson 1987, Hayden and Villeneuve 2011, Krupp 2015). Nevertheless, the utterly visual experience of the sky is undeniable, and it stands to reason that some iconographic motifs might indeed represent celestial bodies, but those representations won't necessarily be immediately obvious to the non-anthropologist, as art is so often produced through a socio-cultural lens (e.g. Lévi-Strauss 1963).

Perhaps less tangibly, the celestial bodies, individually or as part of clusters, are often mythologised, or perhaps, myths and folktales are projected unto them. While not wholly material - as so often they are transmitted orally - these stories frequently provide the 
Pre-print chapter of Handbook of Human Symbolic Evolution (edited by Nathalie Gontier, Oxford University Press)

explanation and justification for artistic representations as well as for material artefacts. Talismans, protective symbols and other icons might indirectly relate to a society's skyscape via some story, written or oral, legend, folk tale or myth that explains or connects the symbology of the artefact to the celestial object. These are, patently, harder to disentangle when only the material record is available, however, in some instances at least, later (written) mythologies can provide keys that unlock a deeper understanding of such material objects and art (e.g. Kristiansen 2012)

\section{First Steps}

As a way to argue that a particular orientation was intentionally incorporated into a prehistoric structure by its builders and not the product of mere chance, archaeoastronomers look for patterns across groups of similar monuments, built around the same time and spread over a given area. This often begins by identifying an orientation of interest - for instance that of an entrance or an axis of symmetry - and getting an expert to, using survey instruments, measure at each site the azimuth (the horizontal angle measured clockwise from geographic north) and the corresponding altitude of the horizon (vertical angle expressing the displacement of the local horizon from a theoretical flat horizon, such as what is visible in open sea). Together with the latitude of the sites these measurements allow for a computation of the celestial object(s) rising or setting in those directions (see, for example, Ruggles 1999). Patterns of orientation can then be sought and checked against the (null) hypothesis that orientation is merely random. Significant deviations from randomness are suggestive of agency, and therefore can be used to argue for intentional alignments to celestial objects.

Although this fieldwork methodology dates back to the early part of the nineteenth century (Lockyer 1909), the statistical concern was not raised until the works of Alexander Thom (e.g. 1972) and, more thoroughly, Clive Ruggles (e.g. 1999), whose research focused primarily upon the British Isles. On the Western Mediterranean, the work was taken by Michael Hoskin who, using survey-grade compass and clinometer, measured the orientation of thousands of prehistoric monuments (Hoskin 2001). A particularly strong case for intentionality was made for the seven-stone "antas" of the Alentejo region in southern Portugal and neighbouring Spanish region of Extremadura. These passage graves are comprised of a megalithic chamber of, invariably, seven uprights and a capstone (Figure 1); and, sometimes, a megalithic corridor extended the entrance to the chamber by a few metres. Radiometric dates indicate that they were built between 3600-3000 BCE (Rocha 2010). 
Pre-print chapter of Handbook of Human Symbolic Evolution (edited by Nathalie Gontier, Oxford University Press)

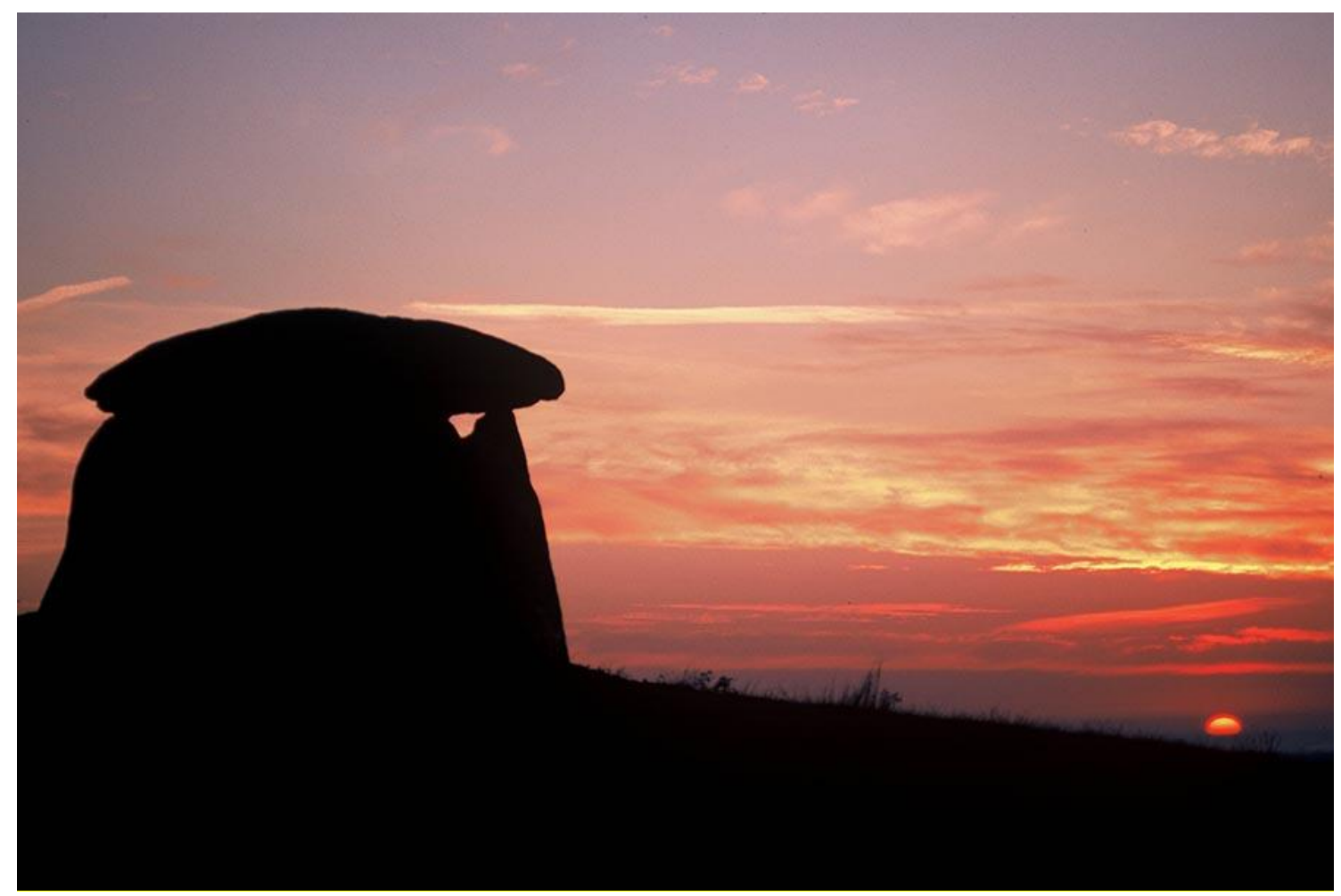

Figure 1. The passage grave of Aldeia da Mata near Crato in northern Alentejo, Portugal, facing the rising sun. Photograph by Luís Tirapicos.

Hoskin determined the orientation of their 'axis of symmetry' by measuring the direction perpendicular to the backstone of the chamber and/or (depending on the case) by measuring the line formed by the middle of the backstone and the midpoint of the corridor. In total, 177 passage graves were surveyed in this manner in the regions mentioned and all of them point towards an azimuth band that is a mere $60^{\circ}$ wide, centred at roughly East (i.e. $90^{\circ}$ of azimuth). Over this wide geographical region, such a strong regularity in orientation could not have been accomplished using topographic referents such as prominent distant peaks - the Alentejo region is, in effect, a very flat province. This suggests that the target used to determine the orientations of these megalithic structures must have been a celestial one.

The azimuthal band of measured orientations agrees almost exactly to the range of sunrise positions throughout the year. This means that, with but a few exceptions, every tomb in the set is oriented within the arc of sunrise. This, Hoskin and others have argued (Hoskin 2002; Belmonte 1999: 62), constitutes strong evidence of an association between these communal tombs and the sun. Effectively, a century before the fieldwork of Hoskin and colleagues, José Leite de Vasconcellos, a Portuguese ethnologist and antiquarian, argued in his book Religiões $d a$ Lusitânia, that the entrances of these passage graves, which were "very frequently facing the Eastern horizon", might have been related to a sun cult (Vasconcelos 1897: 391-392).

If the tombs were oriented to face sunrise on the day when construction began, as Hoskin proposed, then the distribution of azimuths would indicate that this took place predominantly in the spring or autumn. However, the fact that the orientations span the entire solar rising range implies that, in some cases, construction would have commenced in the middle of summer or winter (Hoskin 2001). However, there is circularity of argument here, since one needs to assume 
Pre-print chapter of Handbook of Human Symbolic Evolution (edited by Nathalie Gontier, Oxford University Press)

the alignments are towards the sun in order to assess when in the year the megaliths would have been built; whereas, on the other hand, one has to assume they were built at different times of the year in order to arrive at the conclusion that they must have been oriented to the sun.

An alternative interpretation has been suggested by Da Silva (2004). Since any possible solar orientation can also be interpreted as a lunar orientation, he suggested that the moon rather than the sun was the target of these orientations. A smaller study of 91 passage graves in the same region showed a pattern of orientation that was a close match to the spread of orientations expected of the Spring full moon, therefore providing a much more natural explanation for the variability in orientation. Further north, Silva (2015b) has used a different measurement methodology on similar structures and found much stronger patterns to bright stars, rather than sun or moon (see case study 4 below). Although the debate around which celestial object was being targeted by these prehistoric communities continues, the debate itself in no way undermines the celestial character of the symbolic orientation of these megalithic structures.

\section{Portuguese Prehistoric Skyscapes - Six Case Studies}

Since the pioneering efforts of Michael Hoskin in Iberia, other scholars have taken to the Portuguese countryside visiting and surveying the hundreds of prehistoric sites for potential celestial significance - in many cases extending the research to non-megalithic sites. In this section we take a look at some case studies in skyscape research (Figure 2) that have pushed the methodology forward and stretched our understanding of the prehistoric communities that incorporated celestial symbolism in their structures and art. 
Pre-print chapter of Handbook of Human Symbolic Evolution (edited by Nathalie Gontier, Oxford University Press)

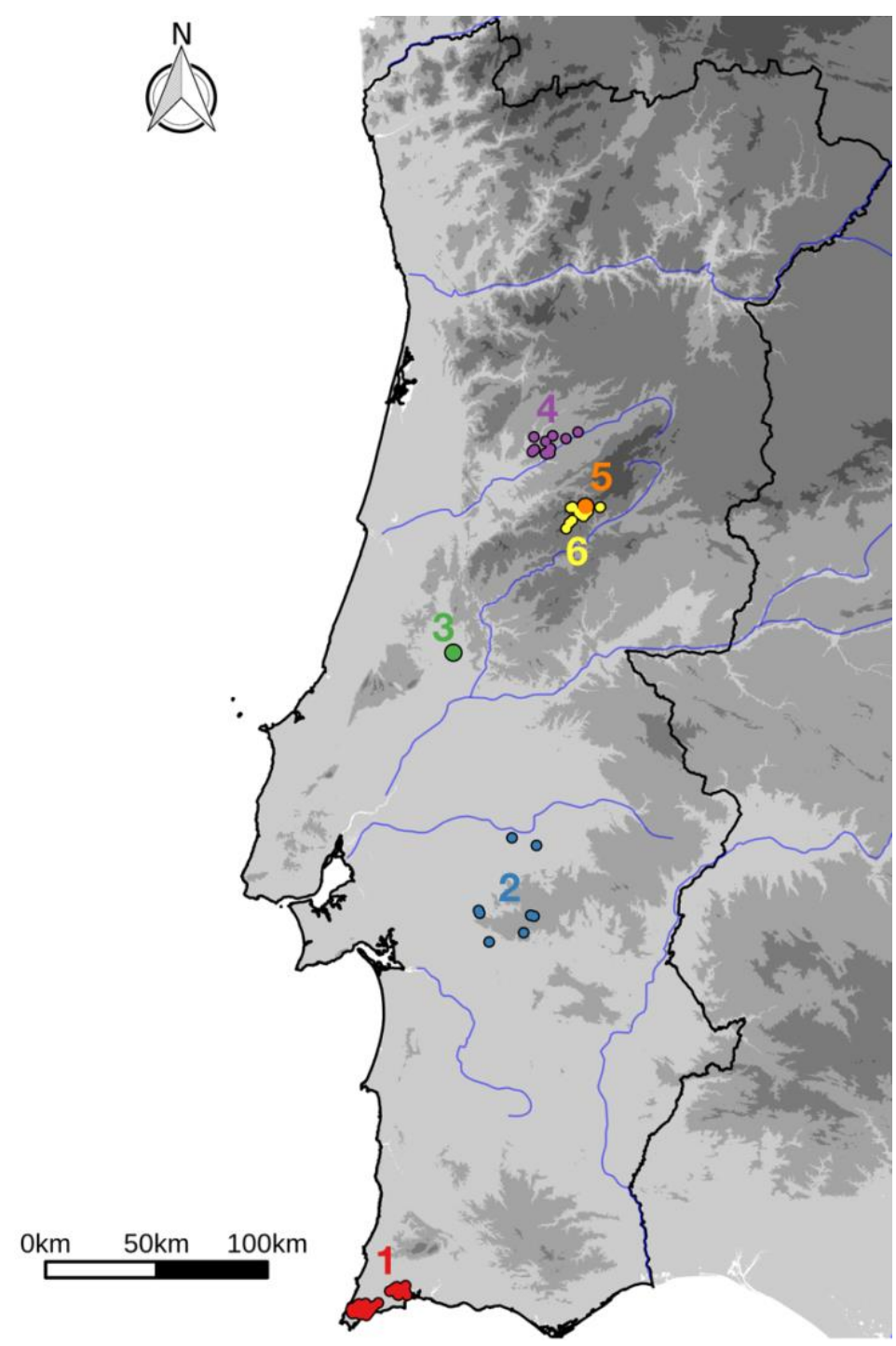

Figure 2. Locations of prehistoric sites discussed in the six case studies of this chapter. Background greyscale is indicative of land elevation above sea level.

\section{Case Study 1 - Early Neolithic menhirs in the southwest of Portugal}

In the southwestern extreme of Europe, in the Algarve region of Portugal, more than 280 menhirs survive to this day as remnants of a magnificent past landscape dotted with white limestone uprights with shining polished faces and carvings possibly enhanced by red ochre paintings (Figure 3 ). About a quarter of the extant menhirs are decorated with engravings that can be considered as developments of serpentiform motifs: simple or double ellipses with or without a long axis, wavy lines and a collar with a single or double cord, with or without halfellipses (Calado 2000). These motifs are very similar to the decorations of pottery found in the nearby Early Neolithic settlement of Cabranosa (Carvalho and Cardoso 2003), suggesting that the menhirs, or at least their decoration, may date to a time between the middle and the end of the 6th millennia BCE (Carvalho 2008, 190). According to Calado (2004) menhirs may represent an anthropomorphic image of the Neolithic man empowered by animal domestication. In fact, several ethnographic records around the world suggest that standing stones are 
Pre-print chapter of Handbook of Human Symbolic Evolution (edited by Nathalie Gontier, Oxford University Press)

anthropomorphic human representations, sometimes of men turned into stone while observing the rising of astral bodies (Frikel 1961).

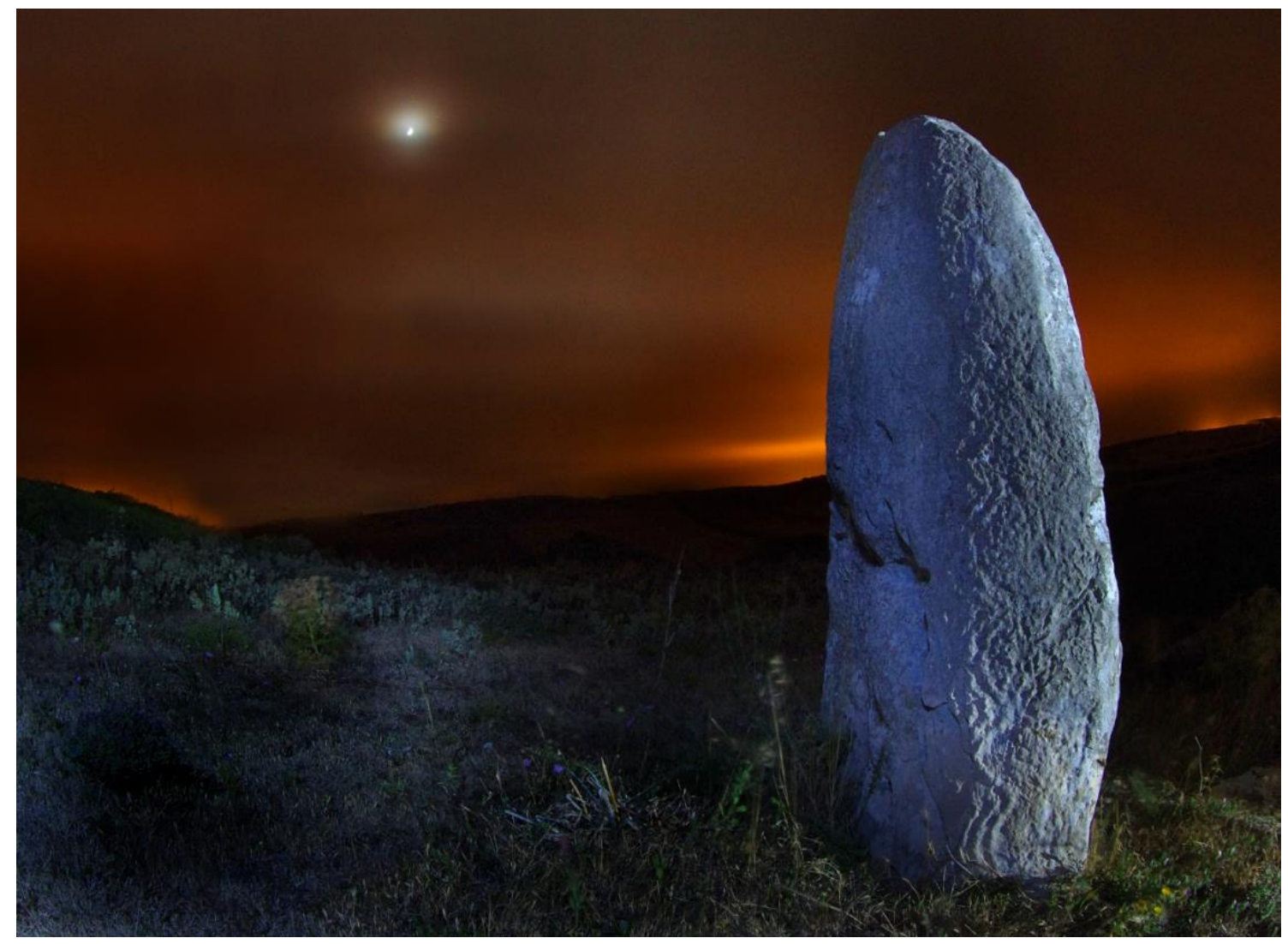

Figure 3. Aspradantas, a standing menhir from Vila do Bispo, Portugal. Photograph by Dinis Cortes.

The places where these menhirs were erected followed several selection rules: the menhirs were erected at higher ground, with smaller slope and therefore with easier access, on slopes turned to the eastern quadrants, keeping visual contact with Monchique mountain and presenting a clustered spatial distribution at small scale that turns into a regular spatial distribution on a grid of approximately 900 meter size, arranged in $\mathrm{N}-\mathrm{S}$ alignments (Pimenta et al, in prep). This type of territory organization suggests a model of occupation around central grid points that may correspond to the settlements. The regular type of territory occupation, that maximizes land resources, would require some sort of social interaction and implies a strong sense of community identity.

The menhirs themselves provide no clues with regards to orientation, but as their placement seems to have been based on a number of selection rules it was investigated whether they might have been placed in locations with horizon features that may have been used as markers for the risings or settings of celestial objects. This analysis suggests an interest in the rising of the stars Altair ( $\alpha$ Aquilae) and Regulus ( $\alpha$ Leo). These two stars would be seen to rise at complementary periods of time: Altair was seen rising between Autumn and Spring, and Regulus between middle of Spring and Autumn - thus framing the period associated with shellfish gathering.

Shellfish activity was of fundamental importance to the local Mesolithic populations and continued through the Neolithic period as shown by the Neolithic reoccupation of the Mesolithic sites of the region (Carvalho 2008). The importance given to shellfish in the area is documented 
Pre-print chapter of Handbook of Human Symbolic Evolution (edited by Nathalie Gontier, Oxford University Press)

by the Early Neolithic cardial style ceramic, whose decoration was created by the impression of the edge of a shell (Cardium edule) - a style that is well represented in the region but relatively rare in other Early Neolithic sites of Portugal (Carvalho 2008, 190-193) - by adornments (like bracelets, pendants, small beads and pins) made from the shells of sea molluscs (Gomes 2013), by the large quantities of shells found in tumuli (Gomes 2008), as well as by funerary offerings and even as a floor or bed on top of which the dead were placed - as in the Pedra Escorregadia Late Neolithic/Early Chalcolithic tomb (Gomes 1994). It is also important to note the seasonality of the region's temporary lagoons, which have their wet period between Autumn and Spring.

Additionally, the most common moon rise position in the northern quadrant coincided with that of the two mentioned stars at the end of the 6th millennia BCE. The moon, especially in its dark and full phases, has always had an important role in agriculture, fishing and shellfishing activities (Oliveira 2015), making it another likely candidate for a celestial referent.

For populations that seemed to have organized their territory in a regular grid and that had to adapt to the seasonality of land and sea resources, a need of calendrical markers for ecological reasons and/or for social activities that would reinforce their bonds seems quite natural. It therefore should not be surprising to find markers to celestial objects whose yearly dynamics matched the seasonal cycles of terrestrial and marine resources important to these Early Neoltihic communities.

\section{Case Study 2 - The Alentejo megalithic open enclosures}

Archaeologists believe that the establishment of Neolithic economies in central Alentejo may have occurred as early as 5600 BCE (Zilhão 2003). However, the first megalithic evidence in this region - comprised of open enclosures - only appears during the Middle Neolithic, that is in the sixth to fifth millennia BCE, predating the communal seven and nine-stone passage graves that later appear in the same area (Calado 2004). The communities that built the enclosures could have been the outcome of a sedentarization process by the Mesolithic populations that previously had occupied the basins of the Tagus and Sado rivers (Calado 2004) or the outcome of colonization by other groups that migrated into this area (Zilhão 2001).

According to Manuel Calado $(2004: 72,82)$, the basic footprint of these enclosures is that of a horseshoe whose opening is to the east. In most of these enclosures the largest menhir is located within this horseshoe limit, at one focus point of the enclosure (Figure 4). In addition, many of the menhirs feature decorations, with the most common motifs being crescents, circles, horseshoes, and crosiers. According to Calado, the enclosures could have been conceived as anthropomorphized standing stones that surrounded a scenic space with an opening to the east. Despite their complexity, the horseshoe shape of these enclosures provides a direction of interest given by that of the major axis of the horseshoe. A statistical analysis of the orientation of these major axes indicates a preference for orientation of the major axis of the enclosures the axis of symmetry that bisects the horseshoe shape and is oriented towards its opening towards the rising position of the Autumn full moon (Pimenta et al 2009a). This celestial event corresponds to the first full moon that rises to the north of the rising position of the sun on the same day - frequently this corresponds to the first full moon after the astronomical Autumn equinox. 
Pre-print chapter of Handbook of Human Symbolic Evolution (edited by Nathalie Gontier, Oxford University Press)

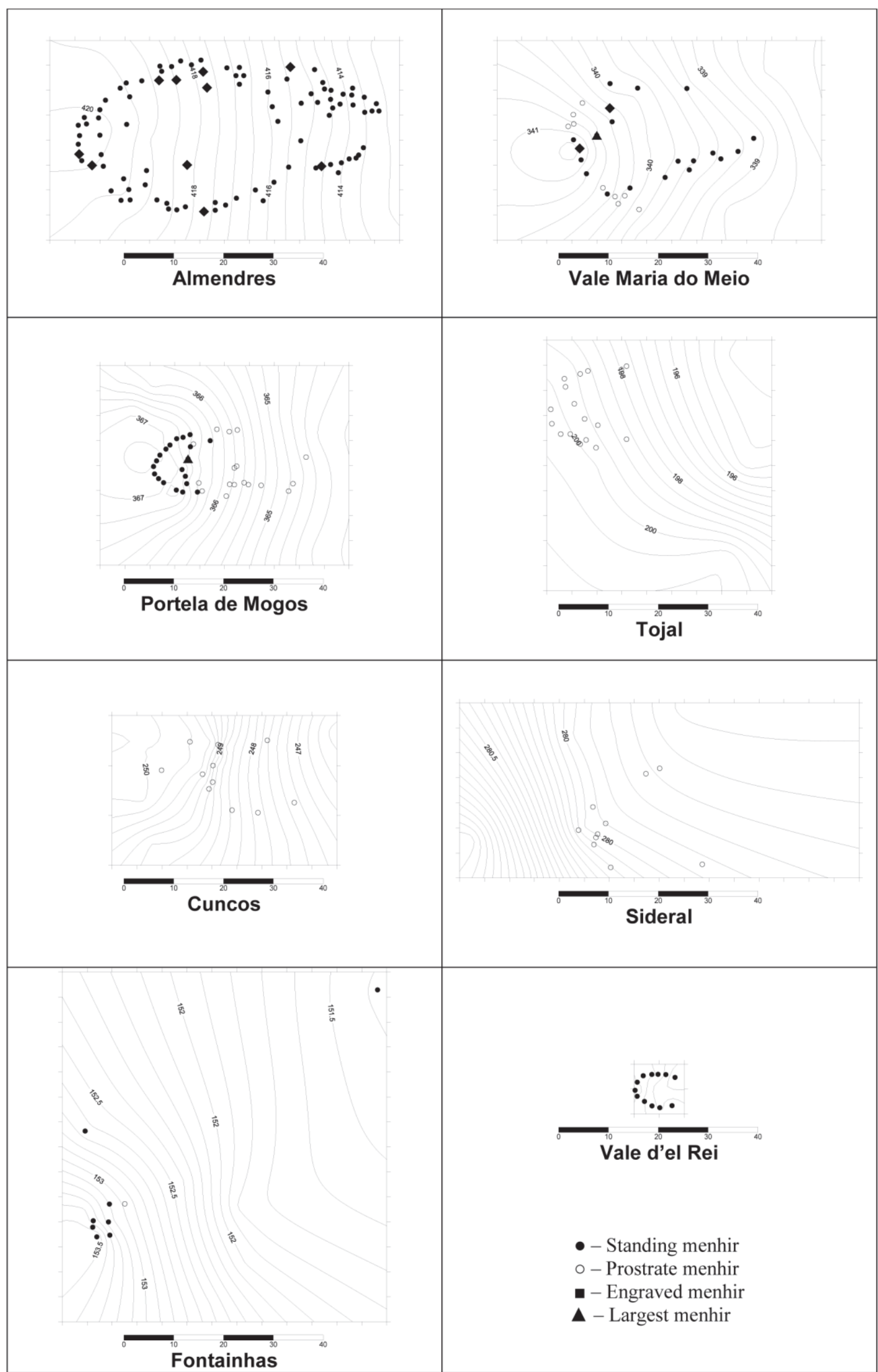


Pre-print chapter of Handbook of Human Symbolic Evolution (edited by Nathalie Gontier, Oxford University Press)

Figure 4. Site plans of the eight enclosures where the menhir positions were known. Geographical north is up and the scale is in meters.

Because these monuments were probably linked with the earliest stages of neolithization in the region, their builders were likely to have had a mixed subsistence strategy involving hunting, gathering, pastoralism and farming (Jorge 1999; Silva et al. 1993) - it is therefore likely that they were seasonally nomadic. The raising of ovicaprids, a feature of these communities, would require fresh pastures away from the flat and dry summers of the landscapes where the enclosures are found. Closer to us in time, the historical record attests to long-distance winter transhumance, herding sheep from the central mountainous areas of Portugal to the pastures of the Alentejo plains. This was practiced at least since the Middle Ages up to the twentieth century and would mean that the shepherds and their sheep would be in the Alentejo region in the colder half of the year, i.e. between October and March (Cruz 2007). The megalithic enclosures could therefore have been primarily used for social and/or religious ceremonies that coincided with the Autumn Full Moon, at the time of the return of these communities to the Alentejo area.

\section{Case Study 3 - Morgado Superior, a collective tomb in a natural cave}

Moving north one leaves behind the wide, flat landscapes of southern Portugal and begins to penetrate the corrugated terrain of central and northern Portugal with its mountain ranges and river valleys. Along the watershed of the Nabão river one finds a cave complex that, not unlike many others, had Neolithic uses.

The route that leads to this complex follows in a certain way the archetype of initiation: the visitor has to leave behind the wide and open horizon and descend into a narrow V-shaped valley, home of the Nabão river, in order to reach the caves (Pimenta 2016). The complex is composed of two caves layered one on top of the other: Morgado Inferior below Morgado Superior. The latter - the one that concerns us here - develops along three circular chambers of decreasing size, aligned along the same axis. Its arrangement is like that of a portal that would allow passage between different worlds, as probably the Central and South American natives or the Australian aborigines would conceive it.

In the first chamber, close to the south wall, more than 200 individuals of both genders, children and adults, were buried together with fragments of speleothems, calcite crystals and river pebbles. Large pieces of speleothems close off this deposition area (Cruz et al 2018; Pimenta 2016). Bones in this burial area have been dated to between 3500 and $2600 \mathrm{BCE}$, corresponding to the Chalcolithic and Bronze Ages. In the second chamber at least two Neolithic burial periods were detected: a first phase was dated to $4850 \mathrm{BCE}$ and a second one to $4000 \mathrm{BCE}$. During the second Neolithic phase the older remains were moved to the sides and the centre of the chamber was occupied.

This second chamber, smaller than the first, provides a more constrained view to the external landscape and, consequently, skyscape. This view would capture the rising Equinoctial full moons, in particular "the" Autumn full moon (Pimenta 2016), which is the first autumnal full moon after the rising sun and full moon have swapped positions in the horizon (Silva and Pimenta 2012). Antares ( $\alpha$ Scorpio) was also visible from this chamber, rising in the axis of the 
Pre-print chapter of Handbook of Human Symbolic Evolution (edited by Nathalie Gontier, Oxford University Press)

cave. It would be visible from around the Autumn equinox until just before the Spring equinox - in other words during the winter half of the year, a period of difficult access to the cave by the river, due to heavy rains and floods. From the Chalcolithic and Bronze Age burial area in the first chamber, however, it would not be possible to see the rising of the Equinoctial full moons nor Antares. The Summer solstice sun, on the other hand, would be seen rising over a facing hilltop.
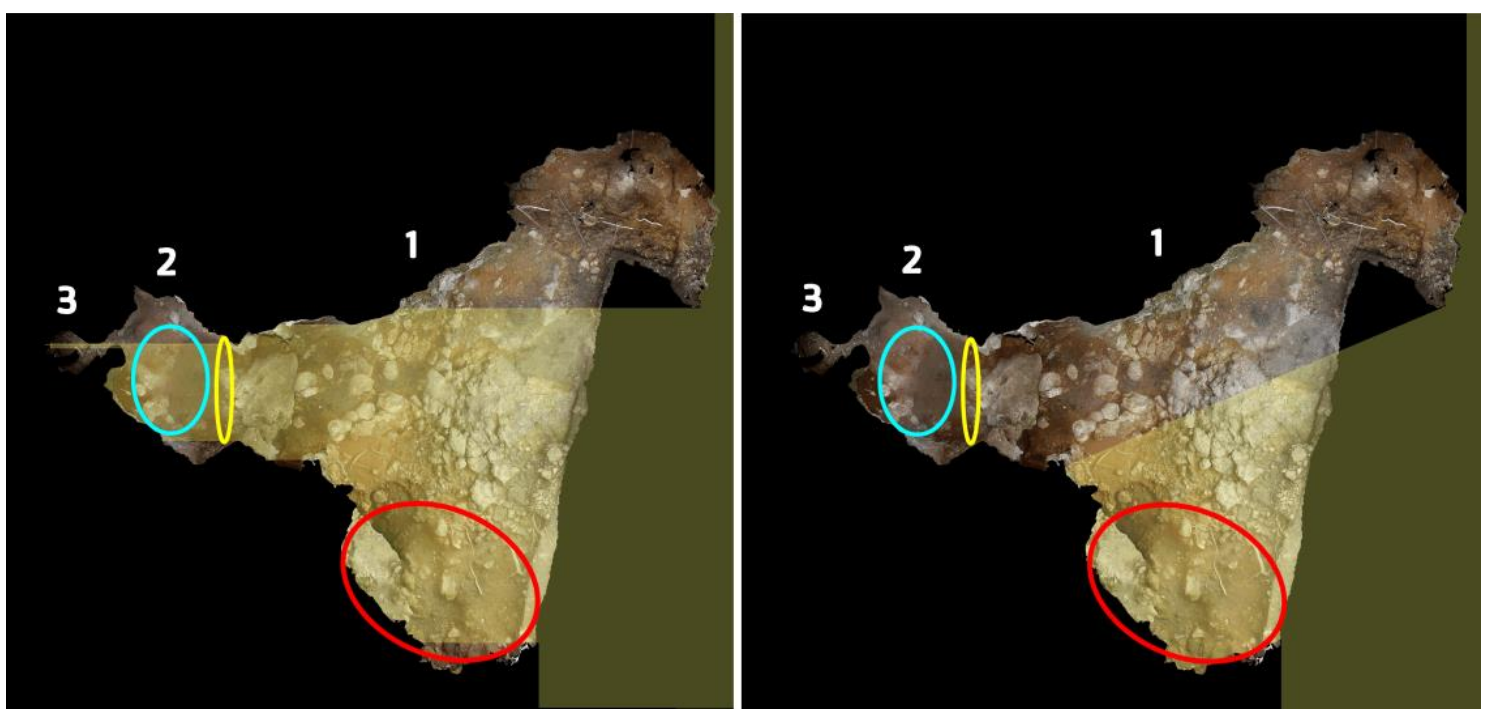

Figure 5. Illumination of the Morgado Superior cave by the light of the rising sun: (left) at the equinox when sunlight penetrates the inner parts of the cave, where the Neolithic burials (yellow and blue ellipses for the first and second Neolithic phases respectively) are located; and (right) at summer solstice when sunlight illuminates only the Chalcolithic and Bronze Age burial area (red circle). The numbers identify the first, second and third chambers. Author composition over orthophoto made by Hugo Pires in 2016.

This could be evidence of a cosmological shift from a lunar or stellar emphasis in the Neolithic to a solar one in the Chalcolithic and Bronze Age. A shift of interest in the seasons of transition (i.e. Spring and Autumn) to the Summer is also apparent. However, further into the cave, in a third chamber, not yet excavated, a special light effect takes place over an artificially placed speleothem which is illuminated by the light of the rising sun only at the Equinoxes (Figure 6). This possible light hierophany inside the third chamber occurs about two days after the spring equinox and about two days before the autumn equinox - dates that may not be random, but rather correspond to a conception of equinox that is obtained by halving the number of days between the solstices (Esteban and Cabrera 2005), as is seen in several pre-Roman Iberian cave sanctuaries of the Iron Age, particularly in the Cueva de la Lobera, where numerous votive artefacts were found associated with belief on a mother-goddess (Esteban et al 2014).

It is possible that different social groups at different prehistoric periods recognized the sacred character of the cave and re-used parts of it for burial purposes, organizing the space according to their specific beliefs, destroying, not recognizing or simply ignoring the symbolism of previous occupations. It is always difficult to interpret single sites such as this one because we cannot discard the very real possibility that these celestial events were not observed by the prehistoric people using the cave - in other words that these "alignments" are merely due to chance. Nevertheless, the evidence suggests these communities had a similar structure and spatial organization as the communities of Alentejo (case study 2) and the Mondego basin (case study 4) that built and used megalithic chambered cairns or passage graves. 
Pre-print chapter of Handbook of Human Symbolic Evolution (edited by Nathalie Gontier, Oxford University Press)

\section{Case Study 4 - Passage graves in the Upper Mondego}

Turning northeast to the Mondego river valley, radiocarbon dates indicate that the first megaliths were built roughly a thousand years after the first Neolithic communities showed up in the region during the fifth millennium BCE (Cruz 1995, Senna-Martinez et al. 2008a, 2008b, Valera 1998). According to Senna-Martinez and Ventura (2008a, 333) the first phase of megalithism in this region would be characterized by structures that featured a small megalithic polygonal chamber and a short corridor or none at all, enclosed by an artificial mound of earth and stone - a passage grave or dolmen. Later, a second phase was comprised of generally larger structures possessing longer corridors and more complex and differentiated forecourts that are suggested to have been used as ceremonial spaces.

Based on the evidence from the Neolithic settlements in the Mondego basin, scholars have proposed a seasonal model for life in the Upper Mondego platform during the Neolithic period. The evidence indicates that small communities sustained themselves primarily by small game hunting, the gathering of acorns and other winter fruits, with agriculture playing only a minor role in their subsistence, if at all (Senna-Martinez and Ventura 2008a, 327). On the other hand, ovicaprids were introduced to the region by the first Neolithic settlers, suggesting that winters had to be spent on low ground, whereas the spring and summer seasons had to be spent on the high pastures of nearby mountain ranges, most notably Serra da Estrela (Senna-Martinez et al. 1997, 663-4; Cruz 2001, 313).

Hoskin surveyed using his methodology, a number of passage graves in this region, detecting some variability in their orientation and, therefore, the lack of a precise pattern in orientation (Hoskin 1998: S62-65). This he interpreted in similar fashion to other passage graves in Iberia: the variability could be explained if they were oriented to sunrise on the day of the beginning of their construction. Since most of the passage graves in this region are oriented E-SE, they match the position of sunrise in the winter half of the year, which is exactly when these Neolithic communities would have been in the river valley where the megalithic structures are found (Senna-Martinez et al 1997).

A different approach is to look not at a single measurement of a supposed axis of symmetry (which is often inexistent since these structures don't adhere to such architectural notions) but to look at the range of possible orientations given by the architecture of each structure. This is to say that one can be more confident of finding an alignment if one considers the entirety of the view afforded by the megalithic structure (the so-called "maximum window of visibility"), rather than making any modern western assumptions of where inside this view a celestial object being targeted should be (Silva 2014). When this methodology was employed a different narrative emerged.

Firstly, Serra da Estrela features in the maximum windows of visibility of all the megalithic sites highlighting the importance of this mountain range to the communities of the Upper Mondego platform. Secondly, there is a pattern in the sense that all the maximum windows overlap in the azimuth range $98-111^{\circ}$ (Figure 6), suggesting that, if there was a celestial object being intentionally targeted by all structures, it would have to rise within that tight azimuthal band. Within this band, there are no significant solar or lunar events but the band matches closely the rising of Aldebaran ( $\alpha$ Taurus), one of the brightest stars in the night-sky, during the phase of megalithic construction in this region. 
Pre-print chapter of Handbook of Human Symbolic Evolution (edited by Nathalie Gontier, Oxford University Press)

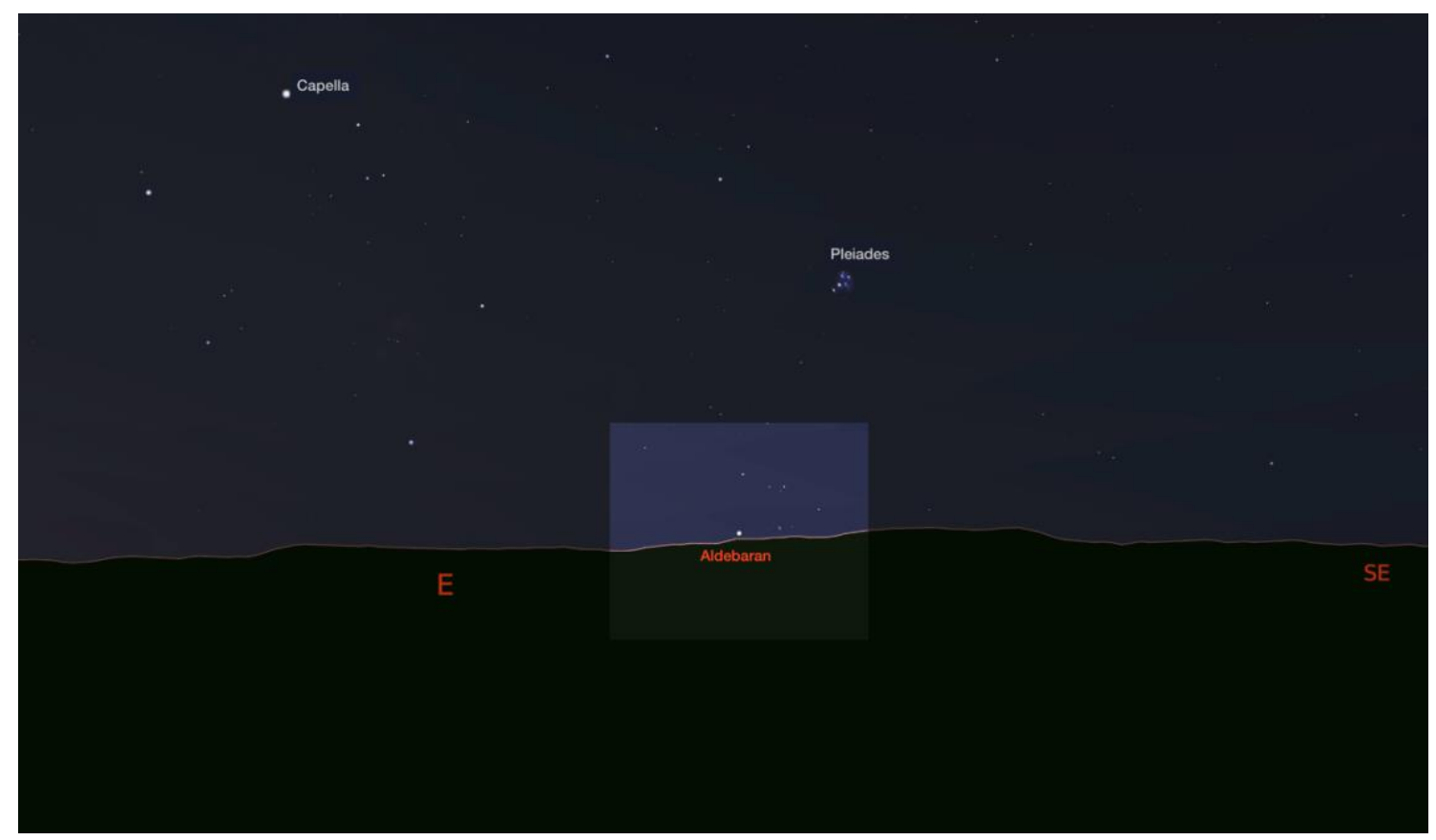

Figure 6. Simulation of the view framed by the passage of Dolmen da Orca (Carregal do Sal) one hour before sunrise on May $1^{\text {st }} 3750 \mathrm{BCE}$, capturing the heliacal rising of Aldebaran. Parts of the sky and horizon not visible from inside the passage grave have been darkened. Image obtained using Stellarium v.0.18.2.

There are many stars in the night sky - even more if one considers that the prehistoric skies would have not suffered from light pollution - but only the brightest of stars will be visible close to the horizon (Schaefer 1993). What makes Aldebaran a likely target is not just the spatial dimension of the alignment but also its temporal dimension - in other words, not just whether the celestial object rises in the right spot of the horizon, but when it does so. Astronomical modelling has revealed that, in the epoch under consideration, Aldebaran would have been seen to rise for the first time in the year towards the end of April or beginning of May - the first observation depending on the right atmospheric conditions (Silva 2013). Therefore, if these Neolithic communities were looking at Aldebaran, as the passage grave alignments suggest, they could have used its so-called heliacal rising as a temporal marker for their transhumant movement to high pastures.

This seems to be supported by local folklore, not surrounding the passage graves themselves, but the peculiar naming of the mountain range which translates to English as "mountain range of the star" (Silva 2015c). There are many variants of its toponymical folktale, but they all agree on it being the story of a shepherd that lived in the Mondego valley. After seeing a star rise above a mountain range on the horizon, the shepherd decided to follow the star into the mountain range. It has been suggested that these folktales might be relics of a transhumant lifestyle that could go back to the Neolithic, when the star, mountain range and passage graves of the Mondego valley were in alignment (Silva 2015c).

Furthermore, while on top of Serra da Estrela for the summer months, if they continued to observe Aldebaran, they would see it set, for the first time in the year, around mid-to-late 
Pre-print chapter of Handbook of Human Symbolic Evolution (edited by Nathalie Gontier, Oxford University Press)

September. This would have occurred on the horizon directly above the river valley where the passage graves are - therefore this too could have been a temporal marker that the time to once more "follow the star", but now unto the valley, was at hand. Aldebaran therefore must have played a central role in the cosmology of these Neolithic communities, at once structuring and being structured by the incessant seasonal displacement, both horizontal and vertical, of these transhumant peoples.

\section{Case Study 5 - A circular enclosure near Serra da Estrela}

A circular enclosure is located on a mountain-top at an altitude of $1079 \mathrm{~m}$ above sea level (Figure 7). Still in schist territory, it is close to the border of the granitic massif of Serra da Estrela. The enclosure is formed by white quartz stones forming a circular shape with a diameter of $12 \mathrm{~m}$. Outside the circle, in the $\mathrm{SE}\left(120^{\circ}\right.$ of azimuth) direction, there is a half-buried stone $1.5 \mathrm{~m}$ away from the circle. Although it was not possible to date this structure, findings in the surrounding area suggest a Bronze Age usage.

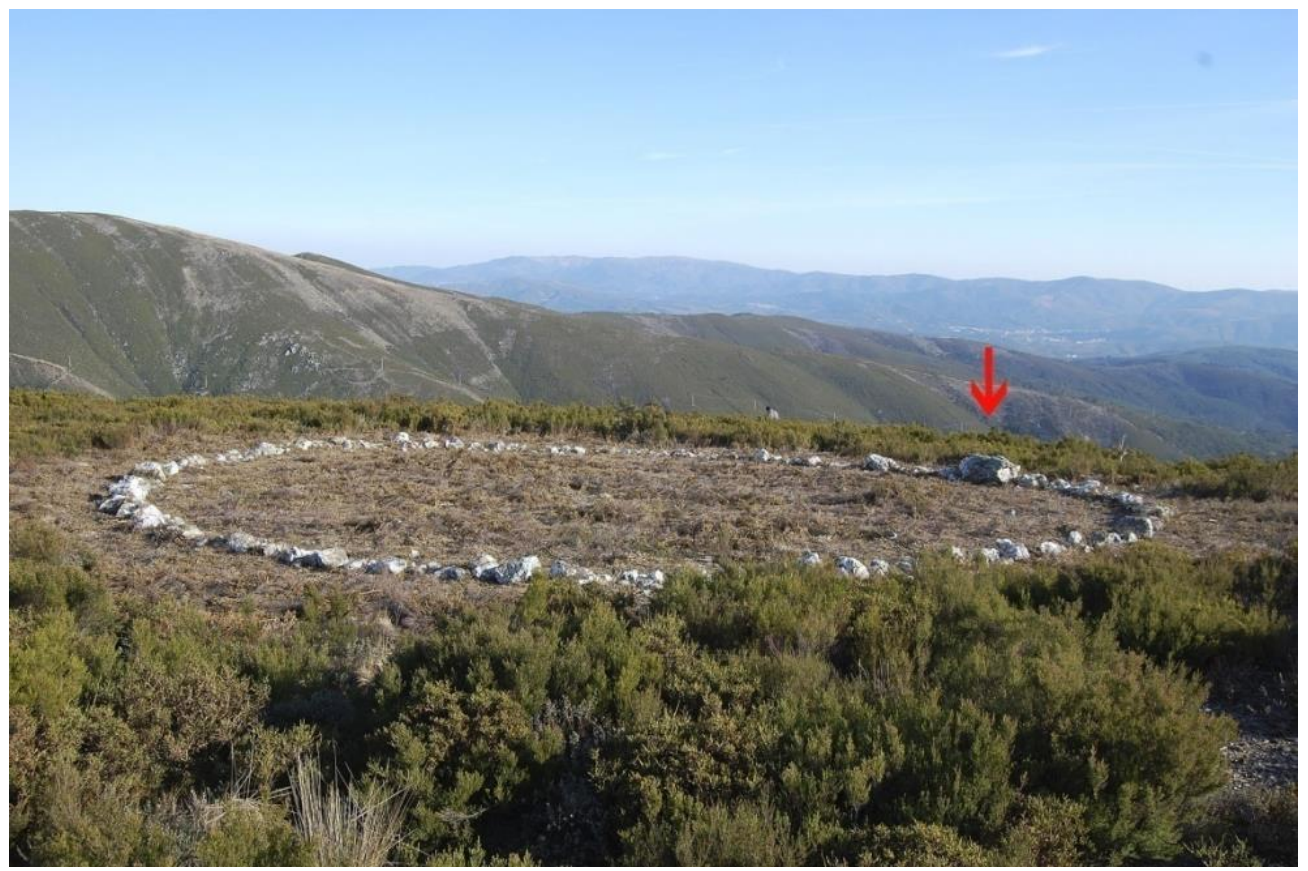

Figure 7. The circular structure Terreiro das Bruxas. The arrow marks the largest stone in the south. Photograph by Sérgio Pereira.

Partial excavation inside the structure did not produce any findings (Pimenta et al 2015). Hovever, along the $120^{\circ}$ azimuth direction that is marked by the large external stone, there are several outcrops that follow the slope down from the structure. Outcrop number two, thirtynine metres away, includes a cover slab suggesting it may have been used as a shelter, cist, fireplace or oven at some point in the past. Near this outcrop a mould for a metal chain was found. Outcrop number four, fifty-five metres away, has an engraved horseshoe whose opening is oriented towards $300^{\circ}$ of azimuth. Outcrop number six, eighty-three metres away, has an engraved podomorph with the same orientation (Pimenta et al 2015). There are a number of other outcrops that follow this same south-eastern direction for about $650 \mathrm{~m}$ when a creek is reached. Dry in the summer, the creek bed is formed by granite slabs with a white quartz line in 
Pre-print chapter of Handbook of Human Symbolic Evolution (edited by Nathalie Gontier, Oxford University Press)

the middle. In a nearby schist slab on a bank of the creek, several engraved podomorphs were found also featuring orientations towards $120^{\circ}$ and $300^{\circ}$ of azimuth (Pimenta et al 2015).

To the northwest of the enclosure, seventy meters away, there is another outcrop that features two vertical slabs forming a corridor that is oriented roughly $300-310^{\circ}$. These "walls" provide an "artificial" elevated marker that, when seen from the largest stone of the circular enclosure, would have framed the Summer Solstice sunset. This emphasis on the $120^{\circ}-300^{\circ}$ direction, which starts at the bottom of the creek and leads to the circle, suggests that the latter was meant to be approached from this creek. Following the trajectory dictated by the many outcrops, an illusion would have been created wherein the sun was perceived to be setting within the circle (Pimenta et al 2015). Upon reaching the top, people would have been able to either observe the crescent of the New Moon setting not far from the position of sunset or, alternatively, turn around to the $\mathrm{SE}$, to observe the Summer full moon rising roughly from the direction from whence they came. This notion of ascent along a predetermined symbolic direction that bridges heaven and earth, and into what we can only conceive of as a sacred place, is likewise mirrored in the cases of the prehistoric caves (case study 2 ) and possibly some passage graves (including those of case study 4), not to mention other international examples such as the processional Avenue at Stonehenge (e.g Parker Pearson 2012).

\section{Case Study 6 - Open Air Rock Art between the Alva and Ceira rivers}

Not far from the previous site, in the area between the Alva and Ceira rivers in central north Portugal, over nine hundred engraved rock outcrops have been recorded (Ribeiro 2014). The petroglyphs were dated, based on their style, from the Palaeolithic, through the Bronze and Iron Ages, up to modern times.

The sites are situated along ridges which have for millennia been used as pathways for human and animal seasonal migrations. The topography of the area, where ridges alternate with deep valleys, provided shelter during the last glaciations to wild herbivores such as aurochs, horses, goat and deer. During post-glacial warming, because of increased summer drought, these herds would have migrated to the fresh mountain pastures, returning in the winter to the sheltered valleys or plains. These movements would certainly have been followed by Palaeolithic hunters and, later, by Neolithic shepherds (as seen in case study 4).

The high-altitude seasonal occupation by Neolithic populations, documented in this area by the presence of lithic tools and funerary monuments (Ribeiro 2014: 385-398; Caninas et al. 2004; Cardoso and González 2002), may have involved pastures created by slash and burn techniques, a practice which was inferred from pollen profiles (Cardoso and González 2002). Summer occupation of the tops of these mountain ranges must have intensified in the Chalcolithic and Bronze Age due to the mining of local tin and copper deposits. Native, as well as foreign, miners, traders and shepherds would cross and occupy the highlands during the summer months, where one may expect that such groups would sometimes come into contact, and possibly conflict, with one other. Further south, in the dry areas of Idanha, Castelo Branco, and even Alentejo (case study 2) and Cáceres (to the east, in Spain), sheep could not be fed properly throughout the year. Shepherds and large flocks of sheep would therefore travel, sometimes for hundreds of kilometres, to come to the mountaintops of the Alva and Ceira regions, where flocks of sheep of both local and distant origin are known to have occupied the highlands (Ribeiro 1940-1941; Trindade 1965). 
Pre-print chapter of Handbook of Human Symbolic Evolution (edited by Nathalie Gontier, Oxford University Press)

The landscape of the region, with high mountain ranges and deep valleys that hinder the movement of people and animals, helped separate areas and isolate the few communities that lived in the valleys. Rock art, which may have been used as orientation reference, probably played an important role in the delimitation of cultural boundaries between the resident population and the itinerant shepherds, miners and traders who seasonally shared the area, either as route or territorial markers (Ribeiro 2006). Some might even have been associated with rituals of atonement or power, such as the ethnographically documented rituals for the protection of flocks (Ribeiro 2014).

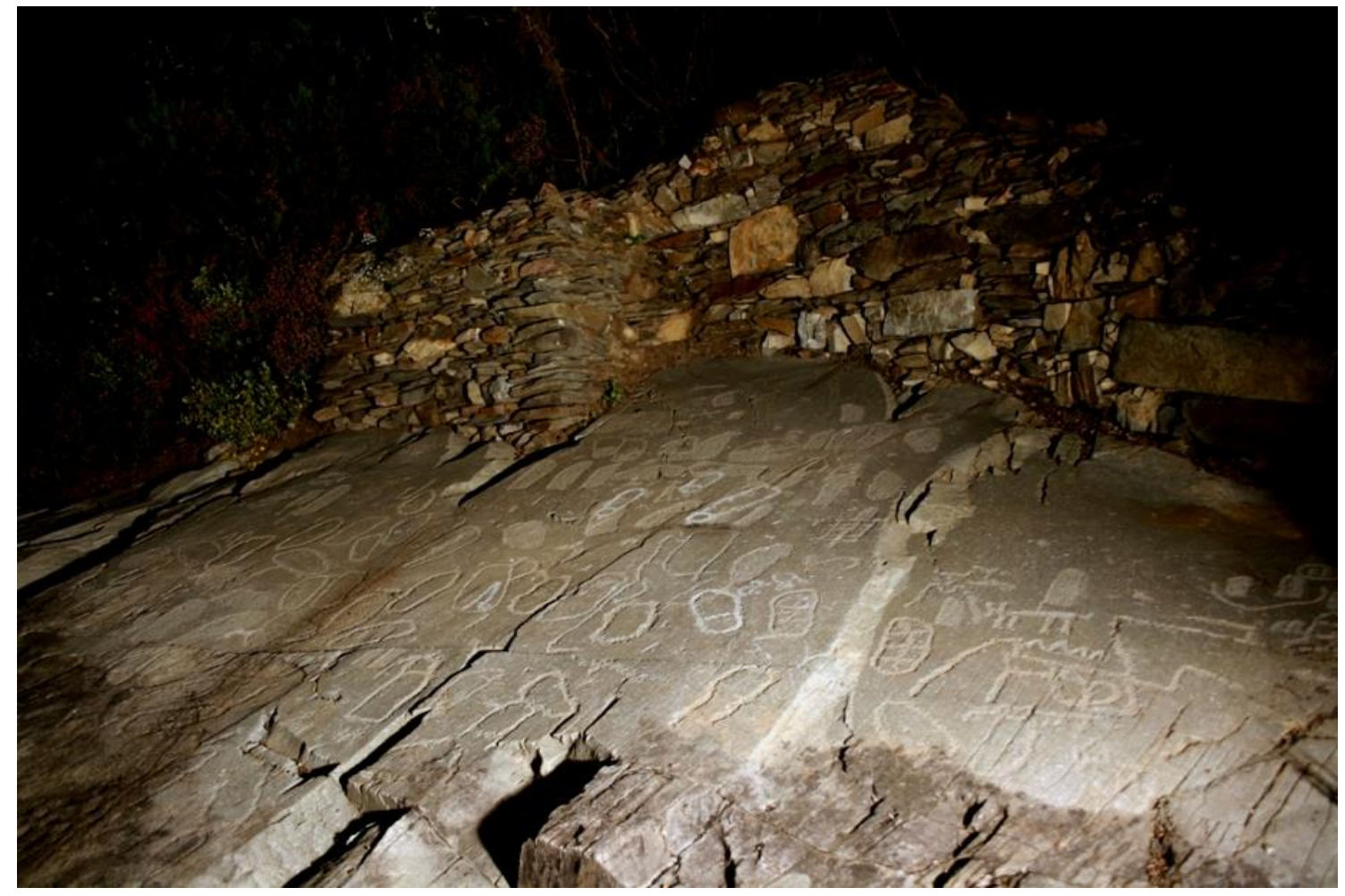

Figure 8. Rasa dos Mouros, an example of an engraved slab with several podomorphs. Photograph by Sérgio Pereira.

In this area the preference is for engraved outcrops to appear at higher altitudes, over 700 metres, dominating the landscape, with smaller slopes that provide a better accessibility. While the slope orientation in the area present a roughly uniform circular distribution, slopes where engraved outcrops are located present a south and southeast predominance. A study of 688 engraved outcrops in the area by Pimenta et al $(2009 \mathrm{~b}, 2015)$ revealed a significant interest in horizon markers in the directions that correspond to the extreme positions of the rising sun i.e. the summer and winter solstices. The podomorphs (depictions of human feet) engraved on these outcrops (Figure 8), however, also provide an orientation, given by their symmetry axis as well as a "walking" direction (when available). These cluster in a very narrow azimuth band that could not be explained by topographic motivations in such a wide area covering more than 2500 $\mathrm{km}^{2}$ (Figure 9). With a seasonal summer occupation and an interest in the eastern horizon, the authors made a possible symbolic association with the rising of the Summer full moon rising. At several sites, around the lunar extreme known as the major lunar standstill, the full moon could be seen "rolling" along a hilltop, sometimes with only the upper limb visible, or even completely 
Pre-print chapter of Handbook of Human Symbolic Evolution (edited by Nathalie Gontier, Oxford University Press)

hidden and appearing as just a bright glow from behind the mountaintop. Another possible explanation could be an interest on the rising of a first magnitude star such as, in the period between 3400 BCE and 1700 BCE, alpha Centauri ( $\alpha$ Cen) which not only matched these orientations but also had its heliacal rising around the Summer Solstice (varying by up to 8 days around it in the period under consideration).

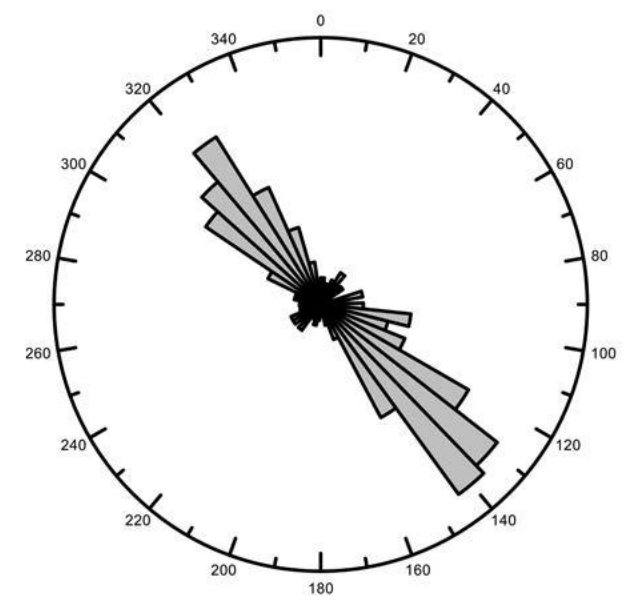

Figure 9. Distribution of the podomorph orientation in azimuth.

The Moon's association with the Mother Goddess in Portuguese folk religion and its later integration into the devotion to St. Mary is well established (Espirito-Santo 1984). Several chapels, built on the top of hills of this region, celebrate the Senhora do Monte (Lady of the Hill), which is often represented as standing on top of a lunar crescent. Generally associated with fertility and the idea of birth and regeneration, they share the myth of a bright appearance over the hill: statues, now worshiped in the mentioned chapels, were once buried in caves to protect them from external enemies (Visigoths, Romans or Moors, depending on context), but miraculously, and in some cases systematically, reappeared on top of the hill, glittering, in the exact same place where the chapels were built. There are several examples from these hilltop chapels in the region, associated with feast dates in summer. In particular, there is at least one recorded case mentioning this in connection to a fertility rite which took place on the eve of St John's (June $24^{\text {th }}$ in the Gregorian calendar) and was still being practiced at the beginning of the last century (Nobre 2006: 148-149). In this fertility rite, young unmarried people would climb by a trail "marked by the feet of many pilgrims in stone" and spend the night on Colcurinho hilltop, near the chapel, until sunrise.

\section{Concluding Remarks}

Much like elsewhere in the world, prehistoric Portuguese communities in different regions and across broad time ranges, included connections to celestial objects in the architecture (whether built or natural) they used. These links, when intentional, provide a point of entry into the highest rung of Hawkes' famous ladder of archaeological inference (Hawkes 1954), which is to say, it opens up research into the minds of prehistoric societies or, at the very least, into those parts of their world(s) that we call the sky and the celestial objects. 
Pre-print chapter of Handbook of Human Symbolic Evolution (edited by Nathalie Gontier, Oxford University Press)

Ranging from a careful choice of location to place standing stones, to the choice of slabs to engrave and the orientation of the engravings, to the construction of megalithic structures, the case studies above illustrate the variety of ways skyscapes find themselves crystalized in the archaeological record. Many other case studies could have been selected - from Portugal or abroad - where similar interactions are observed. For example, similarly to case study 6 , other instances of rock art in Portugal have also been analysed with respect to the skyscape: both in terms of a preference of orientation of open-air engraved slabs (e.g. Côa valley study by Fernandes 2012, 2017) and in terms of symbolic representations of celestial objects (e.g. Pala Pinta rock shelter study by Lima 2013). However, care must be taken not to project our own modern biases unto the symbolic representations of other societies (e.g. Krupp 2015). In a similar way to case study 3 , several are the megalithic monuments where light and shadow were harnessed and integrated into the architecture - Newgrange (Prendergast 2011) and Maeshowe (Hedges 1984) are perhaps the most notorious international examples. In the Iberian Peninsula, however, and closer in style to our case study, several Iron Age cave sanctuaries integrate solar hierophanic elements, as in the Sanctuary of Castellar (Cueva de la Lobera) and La Nariz (Esteban et al. 2014; Esteban and Ibarrs 2016). Finally, in like manner to our case study 2, the orientations of megalithic enclosures and stone circles have also been considered with respect to the celestial objects, as the very popular cases of Stonehenge, the Scottish Recumbent Stone Circles and the Irish Axial Stone Circles attest (e.g. Ruggles 1999).

The above case studies were chosen because they illustrate how prehistoric skyscapes provided not only spatial axes for structural and horizontal alignments but, (one could argue) more importantly, how they served as temporal anchors moored to moments of transition in the environment and in the social lives of these communities. In Portugal, whose subsistence economies have, at least since the Neolithic, been largely tied to pastoralism, it is no wonder that one finds alignments to celestial events that marked key moments in the transhumant cycle - either the beginning of the move to highlands (case study 4), the summer climax $(5,6)$ or the descent to the lowlands (2). But even earlier, and possibly predating the arrival of domesticates, we find that the menhirs of Algarve (case study 1 ) were placed in locations where the rising of two bright stars framed the season for shellfish gathering - the most substantial subsistence activity in the region. The seasonal cycles of landscape, skyscape and society thus appear inextricably linked throughout prehistory.

Identifying such links is but the beginning of the scholars' work and, in fairness, it is the least challenging bit - at least by comparison to what follows. To simply identify a correlation between prehistoric site and sky, even when the alignment is statistically significant, tells us nothing about how that relation was conceived by the people who left behind the archaeological record we study, about its potential animistic conception, symbolic meaning or, more generally, its place in a worldview or ontology. Unlike the anthropologist or the historian, who may have access to ethnographic or textual information on the beliefs and practices of the societies she studies, the archaeologist - and in particular the prehistorian - has only the material, architectural and environmental evidence that has survived the test of time. Perhaps because of this, and also due to its often single-minded focus on statistics, the symbolic, hermeneutic and conceptual aspects of prehistoric archaeoastronomy are largely still in their infancy. However, and despite considerable work ahead, there are paths forward, as illustrated in this chapter. 
Pre-print chapter of Handbook of Human Symbolic Evolution (edited by Nathalie Gontier, Oxford University Press)

\section{References}

Atkinson, Richard J.C. 1966. 'Moonshine on Stonehenge'. Antiquity 40(159): 212-216.

Aveni, Anthony 1993. Ancient Astronomers. Washington, DC: Smithsonian Books.

Aveni, Anthony 2000. Empires of Time: Calendars, Clocks, and Cultures. London and New York: Tauris Parke Paperbacks.

Aveni, Anthony (ed) 2008. Foundations of New World Cultural Astronomy. Boulder: University Press of Colorado

Belmonte, Juan Antonio 1999. Las leyes del cielo - Astronomía y civilizaciones antiguas. Madrid: Temas de Hoy.

Boutsikas, Efrosyni and Ruggles, Clive L. N. 2011. 'Temples, stars, and ritual landscapes: the potential for archaeoastronomy in ancient Greece'. American Journal of Archaeology 115(1): 55-68.

Brady, Bernadette 2012. 'The Egyptian ascension mythology of the Old Kingdom and the phenomenon of star phases'. In H A El Gawad, N Andrews, M Correas-Amador, V Tamorri and J Taylor (eds) Current Research in Egyptology 2011. Oxford: Oxbow Books, pp. 40-47.

Brady, Bernadette 2015a. 'Star phases: the Naked-eye Astronomy of the Old Kingdom Pyramid Texts'. In F Silva and N Campion (eds) Skyscapes: The Role and Importance of the Sky in Archaeology. Oxford: Oxbow Books, pp. 76-86.

Brady, Bernadette 2015b. 'Star-paths, Stones and Horizon Astronomy'. In Pimenta, Fernando, Ribeiro, Nuno, Silva, Fabio, Campion, Nicholas, Joaquinito, Anabela and Tirapicos, Luís (eds) SEAC 2011 Stars and Stones: Voyages in Archaeoastronomy and Cultural Astronomy. BAR International Series 2720. Oxford: Archaeopress.

Campion, Nicholas 2012. Astrology and Cosmology in the World's Religions. New York: New York University Press.

Calado, D., 2000, 'Settlements with menhirs from SW Iberia. Chronology and economy. A statistical approach'. Revista Atlántica-Mediterránea de Prehistoria y Arqueología Social 3.

Calado, Manuel 2004. 'Menires do Alentejo central. Génese e evolução da paisagem Megalítica regional'. Unpublished Ph.D. dissertation, University of Lisbon.

Caninas, J. C., Henriques, F., Batata, C. Batista, A. 2004. 'Novos Dados sobre a Pré-História Recente da Beira Interior Sul'. Revista Estudos Castelo Branco 3.

Cardoso, J. L., Gonzalez, A. 2002. 'Testemunhos da Ocupação Pré-Histórica da Serra da Estrela'. Almadan 11: 242.

Carvalho, A. F. 2008. 'A Neolitização do Portugal Meridional. Os exemplos do Maciço Calcário Estremenho e do Algarve Ocidental'. Promontória Monográfica 12.

Carvalho, A.F. and Cardoso, J.L., 2003, 'A estação do Neolítico antigo de Cabranosa (Sagres). Contribuição para o estudo da neolitização do Algarve'. In V S Gonçalves (ed) Muita gente, poucas antas? Origens, espaços e contextos do Megalitismo. Lisboa: IPA Trabalhos de Arqueologia, pp. 23-43. 
Pre-print chapter of Handbook of Human Symbolic Evolution (edited by Nathalie Gontier, Oxford University Press)

Carlson, J. B. 1987. 'Romancing the stone, or moonshine on the sun dagger'. In J B Carlson and W J Judge (eds) Astronomy and ceremony in the prehistoric Southwest. Albuquerque: Maxwell Museum of Anthropology, pp. 71-88.

Cruz, A., Senna-Martinez, J. C., Santos, L., Relvado, C., Ribeiro, C., Fernandes, T. and Curto, A., 2018 'Upper Morgado Shelter still a peripheral funeral context, or perhaps not? (Tomar, Central Portugal)'. Interchange in Pre- and Protohistory, BAR S2891, edited by Ana Cruz and Juan F. Gibaja, published by BAR Publishing (Oxford, 2018)

Cruz, C. M. O. 2007 'As raças portuguesas de cães de gado e de pastoreio-Aspectos morfológicos e comportamentais'. Unpublished Ph.D. dissertation, Universidade Técnica de Lisboa.

Cruz, D. 1995. 'Cronologia dos monumentos com tumulus do Noroeste peninsular e da Beira Alta'. Estudos Pré-Históricos 3: 81-120.

Cruz, D. 2001. 'O Alto Paiva: megalitismo, diversidade tumular e práticas rituais durante a Préhistória Recente'. Unpublished Ph.D. dissertation, University of Coimbra.

Da Silva, C. Marciano 2004. 'The Spring Full Moon'. Journal for the History of Astronomy XXXV: 475-478

D'Errico, Francesco 1989. 'Palaeolithic Lunar Calendars: A Case of Wishful Thinking?'. Current Anthropology 30(1): 117-118. DOI: 10.1086/203721

Espirito-Santo, M. 1984. A Religião Popular Portuguesa. Lisboa: A Regra do Jogo Edições Lda.

Esteban, César and Ibarrs, José Ángel O. 2016. 'Winter Solstice at the Iberian Cave-Sanctuary of La Nose'. In F Silva, K Malville, T Lomsdalen and F Ventura (eds) The Materiality of the Sky. Lampeter: Sophia Centre Press, pp. 189-196.

Esteban, César, Rísquez, Carmen and Rueda, Carmen 2014. 'A hierophany solar in the Iberian Sanctuary of Castellar (Jaén)', Spanish Archive of Archeology 87:91-107.

Esteban, César and Cabrera, Montserrat 2005. 'Sobre el análisis arqueoastronómico de dos yacimientos tinerfeños y la importância de los equinócios en el ritual aborigen'. Revista Tabona, 13: 187.214.

Frikel, P. 1961. 'Omatanímpe, Os Transformados'. Boletim do Museu Paraense Emílio Goeldi, Antropologia 17.

Fernandes, Batarda 2012. 'Orientação da arte rupestre do vale do Côa: um caso de estudo na distribuição espacial da arte paleolítica ao ar livre'. Trabalhos de Arqueologia 54: 261-271.

Fernandes, Batarda 2017. 'Isto não é um afloramento! É uma rocha de arte rupestre... Factores potenciais de escolha de superfícies de arte rupestre na fase antiga paleolítica da arte do Côa'. In J M Arnaud and A Martins (eds) Arqueologia em Portugal 2017 - Estado da Questão. Lisboa: Associação dos Arqueólogos Portugueses, pp. 991-1001.

Gomes, M. V. 1994, 'O sepulcro colectivo de Pedra Escorregadia (Vila do Bispo, Faro). Notícia da escavação de 1991'. Actas das V Jornadas Arqueológicas 2: 79-91.

Gomes, M. V. 2008, 'Padrão 9 (Vila do Bispo). Um monumento singular do Barlavento Algarvio'. Xelb 8 (1): 75-102. 
Pre-print chapter of Handbook of Human Symbolic Evolution (edited by Nathalie Gontier, Oxford University Press)

Gomes, M. V. 2013, 'Castelo Belinho's village (Portimão Algarve) and the sea. Landscape, resources and symbols'. In J Soares (ed) Pré-História das Zonas Húmidas. Setúbal: MAEDS, pp. 69-84.

Harding, Jan, Johnston, Ben and Goodrick, Glen 2009. 'Neolithic Cosmology and the Monument Complex of Thornborough, North Yorkshire'. Archaeoastronomy 20: 26-51.

Hayden, Brian and Villeneuve, Suzanna 2011. 'Astronomy in the Upper Palaeolithic?'. Cambridge Archaeological Journal 21(3): 331-355. DOI: 10.1017/\$0959774311000400

Hawkes, Christopher 1954. 'Archaeological Theory and Method: Some Suggestions from the Old World'. American Anthropologist 56: 155-168.

Hawkins, Gerald 1963. 'Stonehenge decoded'. Nature 200: 306-308.

Hedges, John W. 1984. Tomb of the Eagles: Death and Life in a Stone Age Tribe. New York: New Amsterdam.

Henty, Liz 2014. 'The Archaeoastronomy of Tomnaverie Recumbent Stone Circle: A Comparison of Methodologies'. Papers from the Institute of Archaeology 24: Art. 15 (online edition). DOI: $10.5334 /$ pia. 64

Hoskin, Michael 2001. Tombs, Temples and their Orientations. Bognor Regis: Ocarina Books.

Hoskin Michael 2002. 'Studies in Iberian Archaeoastronomy: (9) An Overview'. Archaeoastronomy 27 (supplement to Journal for the History of Astronomy 33): S75-S82.

Hutton, Ronald 2013. 'The Strange History of British Archaeoastronomy'. Journal for the Study of Religion, Nature and Culture 7(4): 376-196. DOI: 10.1558/jsrnc.v7i4.376

Iwaniszewski, Stanislaw 2011. 'The sky as a social field'. Proceedings of the International Astronomical Union 7(S278): 20-37. DOI: 10.1017/S1743921311012440

Jorge, Susana Oliveira 1999. Domesticar a terra: As primeiras comunidades agrárias em território português. Lisbon.

Kristiansen, Kristian 2012. 'Rock Art and Religion: The sun journey in Indo-European mythology and Bronze Age rock art'. Adoranten 2012: 69-86.

Krupp, E. C. 2015. 'Crab Supernova Rock Art: A Comprehensive, Critical and Definitive Review'. Journal of Skyscape Archaeology 1(2): 167-197. DOI: 10.1558/jsa.v1i2.28255

Lévi-Strauss, Claude 1963. 'Split Representation in the Art of Asia and America'. In C. Lévi-Strauss (ed) Structural Anthropology. Basic Books, pp. 245-268.

Lima, Paulo 2013. 'Avaliação de Novas Metodologias Espectrais e de Modelação Tridimensional Digital no Estudo da Arte rupestre - Resultados da sua aplicação no estudo do abrigo da Pala Pinta (Alijó), Trás-os-Montes'. Unpublished M.Sc. dissertation, University of Porto.

Lockyer, Norman 1909. Surveying for Archaeologists. London: Macmillan and Co., Ltd.

Malville, J. McKim 2015a. 'Preface: Meaning and Intent in Ancient Skyscapes - An Andean Perspective' In F Silva and N Campion (eds) Skyscapes: The Role and Importance of the Sky in Archaeology. Oxford: Oxbow Books, pp. ix-xvi. 
Pre-print chapter of Handbook of Human Symbolic Evolution (edited by Nathalie Gontier, Oxford University Press)

Malville, J. McKim 2015b. 'Chimney Rock and the Ontology of Skyscapes: How Astronomy, Trade, and Pilgrimage Transformed Chimney Rock'. Journal of Skyscape Archaeology 1(1): 39-64. DOI: 10.1558/jsa.v1i1.26954

Marshack, Alexander 1991. The Roots of Civilization. New York: Moyer Bell Limited.

McCluskey, Stephen C. 2015. 'Orientation of Christian Churches'. In C. L. N. Ruggles (ed) Handbook of Archaeoastronomy and Ethnoastronomy. New York: Springer, pp.17031710. DOI: 10.1007/978-1-4614-6141-8_173

Nobre, C. G. A. 2006. Vide Memorial - Camélias Brancas, volume I. Coimbra: Ediliber.

Oliveira C. 2015 'The cosmos in portuguese popular tradition: a bibliographic and fieldwork approach'. In F. Pimenta, N. Ribeiro, F. Silva, N. Campion, A Joaquinito and L. Tirapicos (eds) SEAC 2011 Stars and Stones: Voyages in Archaeoastronomy and Cultural Astronomy, BAR S2720, Oxford: BAR Publishing, pp. 124-129.

Parker Pearson, Mike 2012. Stonehenge: Exploring the Greatest Stone Age Mystery. London: Simon \& Schuster.

Pimenta, F. 2015. 'Astronomy and Navigation'. In C. L. N. Ruggles (ed) Handbook of Archaeoastronomy and Ethnoastronomy. New York: Springer, pp.43-65. DOI: 10.1007/978-1-4614-6141-8_7

Pimenta, F. 2016. 'A cave with a view: Landscape and skyscape orientation of the caves with funerary occupancy in the meanders of Nabão River'. Antrope 4: 149-152.

Pimenta, F., Tirapicos, L. and Smith, A. 2009a. 'A Bayesian approach to the orientations of central Alentejo megalithic enclosures', Archaeoastronomy 22: 1-20.

Pimenta, F. Ribeiro, N., Smith, A., Tirapicos, L. 2009b. 'The Sky and the Landscape of Rock Art in the Ceira and Alva Basins'. In J. A. Rubiño-Martín, J. A. Belmonte, F. Prada and A. Alberdi (eds) Cosmology Across Cultures. San Francisco: Astronomical Society of the Pacific, pp. 359-363.

Pimenta F., Ribeiro N., Smith A., Joaquinito A., Pereira S. and Tirapicos L. 2015 'Open air rock art between Alva and Ceira rivers: a voyage through mining, trading, tranhumance routes and the orientation in the landscape'. In F. Pimenta, N. Ribeiro, F. Silva, N. Campion, A Joaquinito and L. Tirapicos (eds) SEAC 2011 Stars and Stones: Voyages in Archaeoastronomy and Cultural Astronomy, BAR S2720, Oxford: BAR Publishing, pp. 224239.

Pimenta, F., Soares, R., Smith, A. and Silva, F. in prep. 'Landscape, Skyscape and Mindscape: the location and orientation of menhirs from southwestern Portugal'.

Prendergast, Frank 2011. Linked Landscapes: Spatial, Archaeoastronomical and Social Network Analysis of the Irish Passage Tomb Tradition. Unpublished PhD dissertation, University College Dublin.

Rappenglück, Michael A 2015. 'Possible Astronomical Depictions in Franco-Cantabrian Paleolithic Rock Art'. In C. L. N. Ruggles (ed) Handbook of Archaeoastronomy and Ethnoastronomy. New York: Springer, pp.1205-1212. DOI: 10.1007/978-1-4614-61418_116 
Pre-print chapter of Handbook of Human Symbolic Evolution (edited by Nathalie Gontier, Oxford University Press)

Ribeiro, O. 1940-1941. 'Contribuição para o estudo do pastoreio na Serra da Estrela'. Revista da Faculdade de Letras 7 (1-2): 213-303.

Ribeiro, N.M.C. 2014. 'Manifestaciones de Arte Rupestre en las cuencas hidrográficas de los ríos Ceira, Alva y en las áreas limítrofes de las cuencas hidrográficas de los ríos Zêzere y rio Unhais'. Unpublished PhD dissertation, Salamanca University.

Ribeiro, N. 2006. 'Open air Rock in the Ceira and Alva River Valleys. Some Symbols'. In F. Coimbra and L. Dubal (eds) Symbolism in Rock Art. Oxford: BAR Publishing, pp. 43-49.

Rivard, Jean-Jacques 1970. 'A hierophany in Chichen Itza'. Katunob 7(3): 51-55.

Rocha, Leonor 2010. 'As origens do megalitismo funerário alentejano. Revisitando Manuel Heleno'. Promontoria 7/8: 45-98.

Ruggles, Clive L. N. 1999. Astronomy in Prehistoric Britain and Ireland. New Haven and London: Yale University Press.

Ruggles, Clive L. N. (ed) 2015a. Handbook of Archaeoastronomy and Ethnoastronomy. New York: Springer

Ruggles, Clive L. N. 2015b. 'Calendars and Astronomy'. In C. L. N. Ruggles (ed) Handbook of Archaeoastronomy and Ethnoastronomy. New York: Springer, pp. 15-30. DOI: 10.1007/978-1-4614-6141-8_4

Ruggles, Clive L. N. and Saunders, Nicholas J. 1993. 'The Study of Cultural Astronomy'. In C. L. N. Ruggles and N. J. Saunders (eds) Astronomies and Cultures. Niwot: University Press of Colorado, pp. 1-31.

Senna-Martinez, J. C., López-Plaza, M. S. and Hoskin, M. 1997. 'Territorio, ideología y cultura material en el megalitismo de la plataforma del Mondego (Centro de Portugal).' In A. A. R. Casal (ed) O Neolítico Atlántico e as Orixes do Megalitismo. Santiago de Compostela: Universidade de Santiago de Compostela, pp. 657-676.

Senna-Martinez, J. C. and Ventura, J. M. Q. 2008a. 'Do Mundo das Sombras ao Mundo dos Vivos: Octávio da Veiga Ferreira e o Megalitismo da Beira Alta, Meio Século Depois' Estudos Arqueológicos de Oeiras 16: 317-50.

Senna-Martinez, J. C. and Ventura, J. M. Q. 2008b. 'Neolitização e Megalitismo na Plataforma do Mondego: Algumas Reflexões sobre a Transição Neolítico Antigo/Neolítico Médio'. In M. S. Hernández Pérez, J. A. Soler Díaz and J. A. López Padilla (eds) Actas del IV Congreso del Neolítico Peninsular, Tomo II. Alicante: Museo Arqueológico de Alicante, pp.77-84.

Schaefer, Bradley E. 1993. 'Astronomy and the Limits of Vision', Vistas in Astronomy 36: 311361.

Silva, Armando Coelho F. da, Luís Raposo, and Carlos Tavares da Silva 1993. Pré-história de Portugal. Lisbon: Universidade Aberta.

Silva, Fabio 2013. 'Landscape and Astronomy in Megalithic Portugal: the Carregal do Sal Nucleus and Star Mountain Range.' Papers from the Institute of Archaeology 22: 99-114. DOI: $\underline{10.5334 / \text { pia. } 405}$ 
Pre-print chapter of Handbook of Human Symbolic Evolution (edited by Nathalie Gontier, Oxford University Press)

Silva, Fabio 2014. "'A Tomb with a View": New Methods for Bridging the Gap Between Land and Sky in Megalithic Archaeology'. Advances in Archaeological Practice: A Journal of the Society of American Archaeology 1(2): 24-37. DOI: 10.7183/2326-3768.2.1.24

Silva, Fabio 2015a. 'The Role and Importance of the Sky in Archaeology: an introduction'. In F Silva and N Campion (eds) Skyscapes: The Role and Importance of the Sky in Archaeology. Oxford: Oxbow Books, pp. 1-7.

Silva, Fabio 2015b. 'The View from Within: a 'Time-Space-Action' Approach to Megalithism in Central Portugal'. In F Silva and N Campion (eds) Skyscapes: The Role and Importance of the Sky in Archaeology. Oxford: Oxbow Books, pp. 120-139.

Silva, Fabio 2015c. "'Once Upon a Time...": When Prehistoric Archaeology and Folklore Converge'. Journal for the Academic Study of Religion 28(2): 158-175. DOI: 10.1558/jasr.v28i2.26595

Silva, Fabio 2017. Defining Skyscape [online]. Accessed February 2018, http://sophiacentrepress.com/2017/04/22/defining-skyscape/

Silva, Fabio and Henty, Liz 2018. 'Editorial'. Journal of Skyscape Archaeology 4.1: 1-5. DOI: 10.1558/jsa.36090

Silva, Fabio and Pimenta, Fernando 2012. 'The Crossover of the Sun and the Moon'. Journal for the History of Astronomy 43(2): 191-208. DOI: 10.1177/002182861204300204

Sofaer, Anna, Zinser, Volker and Sinclair, Rolf M. 1979. 'A unique solar marking construct'. Science 206 (4416): 283-291

Sprajc, Ivan 2018. 'Zenith and Nadir Passages of the Sun in Mesoamerica'. Journal of Skyscape Archaeology 4(1): 108-117. DOI: 10.1558/jsa.36092

Thom, Alexander 1972. Megalithic Sites in Britain. Oxford: Oxford University Press.

Trindade, M. J. L. 1965. Alguns problemas do pastoreio, em Portugal, nos séculos XV e XVI. Do Tempo e da História 1: 113-134.

Valera, A. C. 1998. 'A Neolitização da Bacia Interior do Mondego'. Estudos Pré-Históricos 6: 13148.

Vasconcelos, José Leite de 1897. Religiões da Lusitania, vol. 1. Lisboa: Imprensa Nacional.

Ventura, Frank, George Foderá Serio and Hoskin, Michael 1993. 'Possible tally stones at Mnajdra, Malta'. Journal for the History of Astronomy 24: 171-183.

Zilhão, J. 2001. 'Radiocarbon evidence for maritime pioneer colonization at the origins of farming in west Mediterranean Europe'. Proceedings of the National Academy of Sciences 98(24): 14180-5.

Zilhão, J. 2003. 'The Neolithic Transition in Portugal and the Role of Demic Diffusion in the Spread of Agriculture across West Mediterranean Europe'. In A. J. Ammerman and P. Biagi (eds) The Widening Harvest: The Neolithic Transition in Europe. Looking Back, Looking Forward. Boston: Archaeological Institute of America, pp. 207-223. 